\title{
Erotiese oordrag en teenoordrag as psigologiese fenomeen in 'n pastorale relasie $^{1}$
}

\author{
Dreyer T F \& Dreyer T F J \\ Hervormde Teologiese Kollege \\ Universiteit van Pretoria
}

\begin{abstract}
The psychological phenomenon of erotic transference and countertransference within the framework of pastoral care

This article aims to discuss the psychological phenomenon of transference and countertransference in therapeutical relationships. This phenomenon often leads to a sexual relationship resulting in emotional and psychological damage to both partners. The cause of this destructive sexual relationship is based on the therapist's misunderstanding of positive transference within the therapeutic relationship. The therapist, unknowingly in most instances, misuses his or her position of trust for sexual exploitation of the client. This phenomenon also manifests in pastoral relationships. This article describes the phenomenon and provides possible guidelines to the pastor in order to identify and prevent the occurrence of "sex in the forbidden zone."
\end{abstract}

Dr Tower was letting me get close to him through our sexual relationship. The way I saw it, I had nothing to lose. Of course, I was wrong about that!

\section{INLEIDING}

(Rutter 1991:83)

Die verskynsel van predikante wat in hulle pastoraat betrokke raak in seksuele verhoudings neem steeds toe. Die situasie binne die Nederduitsch Hervormde Kerk van Afrika (voortaan NHK) behoort die aktualiteit van die onderwerp voldoende te illustreer. Statistiek van die NHK, toon dat gedurende die afgelope elf jaar (1990-2000) 79 predikante die bediening verlaat het. In

\footnotetext{
${ }^{1}$ Hierdie artikel is gebaseer op T F Dreyer se BD-skripsie, getitel "Erotiese oordrag en teenoordrag as psigologiese fenomeen in die pastorale relasie". Die skripsie is voorberei onder leiding van prof dr T F J Dreyer, Fakulteit Teologie, Universiteit van Pretoria (2000).
} 


\section{Erotiese oordrag en teenoordrag}

24 van hierdie gevalle hou die redes vir die uittrede verband met seksuele verhoudings, voortspruitend uit pastorale relasies (Nederduitsch Hervormde Kerk van Afrika 1990-2000 = NHK 1990-2000). Indien hierdie getal as 'n persentasie van die aantal diensdoende predikante oor die genoemde periode uitgedruk word, dui dit daarop dat 7,3\% van predikante betrokke was by seksuele verhoudings in 'n pastorale relasie. Hierdie getal betrek slegs die gevalle wat onder die aandag van die Kommissie van die Algemene Kerkvergadering gekom het. Hoeveel ander gevalle is daar, waarvan daar nooit gepraat of gehoor word nie? Laaser (1992) beskryf die verskynsel as: "The secret sin", juis omdat dit in 'n atmosfeer van vertroulikheid plaasvind en beide partye, asook kollegas mekaar probeer beskerm. Navorsing toon dat meer as tien persent van alle spirituele leiers in Amerika al betrokke was by 'n seksuele verhouding in die pastoraat (Rutter 1991:41). Jimmy Swaggart is 'n goeie voorbeeld hiervan. Hy was by meer as een insident betrokke (Seaman 1999:339). Indien ons hierdie persentasie (10\%), soos in die navorsing aangedui, projekteer op die getal diensdoende gemeentepredikante (335) in 2000 (NHK 2000:20), kan die afleiding gemaak word dat die frekwensie van hierdie fenomeen waarskynlik in die omgewing van 33 predikante sal wees. Alhoewel statistieke in ander kerke nie nagegaan is nie, kan dit met redelike sekerheid aanvaar word dat die probleem in ander kerke net so akuut is.

Hierdie seksuele verhoudings veroorsaak onberekenbare skade aan die persoon van die predikant, ${ }^{2}$ sy huisgesin en die dame wat by die verhouding betrokke is. Die gemeente in die besonder, maar ook die kerk in die algemeen, word intens na binne deur sulke voorvalle geraak. Die beeld van die kerk word ook negatief na buite geskaad, veral wanneer dit in die openbare pers berig word.

Die navorsing berus op die vermoede dat predikante nie altyd bewus is van "erotiese oordrag" en hulle eie "teenoordrag" as psigologiese fenomene in 'n pastorale situasie nie. Indien predikante meer bewus gemaak kan word van hoe en waarom oordrag manifisteer, sal hulle nie so maklik verkeerdelik daarop reageer nie. As predikante oor die nodige kennis van die fenomeen asook oor die basiese hanteringsmeganismes beskik, sal hulle die verskynsel korrek kan hanteer. Die navorsingsdoel is dus om te probeer bepaal watter voorkomingsmaatreëls en hanteringsmeganismes in die pastroale situasie aangewend kan word om seksuele verhoudings as gevolg van erotiese oordrag en teenoordrag te voorkom. Daar sal ook ondersoek ingestel word na

\footnotetext{
${ }^{2}$ In hierdie ondersoek word daar slegs gefokus om die manlike predikant omdat daar nog nie voldoende navorsingsresultate beskikbaar is om die voorkoms van hierdie fenomeen onder vroue-predikante te bepaal nie.Navorsing toon wel aan dat die fenomeen manifesteer in ander terapeutiese dissiplines waarby vroue as terapeute betrokke is. Die verskynsel sal dus waarskynlik ook by vroue-predikante in pastorale relasies manifesteer.
} 
die moontlikheid van 'n gedragskode om die pastor te kan help om sodanige verhoudings te vermy.

Met die navorsing sal gepoog word om:

- $\quad$ Die omvang van die verskynsel "erotiese oordrag" en verkeerde "teenoordrag" in hulpverleningsprofessies te identifiseer.

- $\quad$ Die faktore wat aanleiding gee tot erotiese oordrag en verkeerde teenoordrag te beskryf.

- $\quad$ Die manifistering van erotiese oordrag in die pastoraat te analiseer.

- $\quad$ Moontlike hanteringsmeganismes as riglyne aan te bied.

- $\quad$ Optrede ter voorkoming van verkeerdelike teenoordrag, asook moontlike gedragskodes vir die pastor te ontwerp.

\section{EROTIESE OORDRAG AS FENOMEEN}

\subsection{Oorsig van die bestaande navorsing}

Oordrag as fenomeen is alreeds deur die eerste psigoloë opgemerk. So het Freud met sy psigoanalise bewus geword van die groot impak wat 'n pasiënt se projeksies op die terapeut het. Hy het na hierdie fenomeen verwys as oordrag wat die terapeutiese situasie emosioneel heeltemal kan oorheers indien die terapeut die verkeerde teenoordrag openbaar (Mansfield 1996:2). Freud poog ook om die terapeut te waarsku teen hierdie verskynsel wat tot die pasiënt se nadeel kan strek as dit nie reg benader word nie. Oordrag kan so 'n groot invloed op die terapeutiese situasie uitoefen dat alle perspektief verloor word. In sy boek "Postscript to the question of lay analysis" sê Freud (1927: 257): "For it is not greatly to the advantage of patients if their physician's therapeutic interest has to be marked by an emotional emphasis. They are best helped if he carries out his task coolly and keeping as closely as possible to the rules."

Carson, Butcher en Minneka (1996:632) definieer oordrag as die pasiënt se projeksies van gevoelens en ervarings van vorige verhoudings, met byvoorbeeld 'n ouer, op die terapeut. Hierdie algemene verskynsel van oordrag kan positief of negatief van aard wees, afhangende van die vorige ervaring (vgl ook Loewald 1986; Schaeffer 1998). Miller en Jackson (1995:37) beskryf oordrag as die verplasing van gevoelens en persepsies van ander verhoudings reëel of surreëel, vanaf die pasiënt na die terapeut. Hierdie oordrag kan wissel vanaf agressie tot erotiese oordrag (Miller \& Jackson 1995:38). 


\section{Erotiese oordrag en teenoordrag}

Die tipe oordrag waarop daar in hierdie studie gekonsentreer sal word, is erotiese oordrag. Wrye en Welles (1997:46) beskryf erotiese oordrag as die stadium waar jy jou terapeut geïdealiseer het tot die punt waar jy glo dat hy jou perfekte "lover" is. Natterson (1991:33) is van mening dat die term erotiese oordrag beteken om al jou onbewuste bewondering vir 'n werklike geliefde te projekteer op die terapeut. Die insidensie van die fenomeen is baie hoog, maar as gevolg van die sensitiewe aard van die fenomeen word daar baie min hieroor gepraat of geskryf (Rutter 1991:36). "It is not unusual for feelings of love, caring and attraction to take on an erotic charge in therapy. The many ethical implications and cultural taboos may discourage clinicians from fully exploring these important transference dynamics" (Corelli) ${ }^{3}$.

\subsection{Beskrywing van die "forbidden zone"}

Die begrip "forbidden zone" word in die literatuur gebruik as aanduiding van 'n terapeutiese vertrouensverhouding wat as gevolg van seksuele intensies misbruik word.

Rutter (1991:25) definieer "sex in the forbidden zone" as: "Sexual behaviour between a man and a woman who have a professional relationship based on trust, specifically when the man is the woman's doctor, psychotherapist, pastor, lawyer, teacher, or workplace mentor."

As die terapeut nie hierdie erotiese oordrag as fenomeen herken nie, reageer hy gewoonlik verkeerdelik hierteenoor en betree hy die sogenaamde verbode sone waarna Peter Rutter verwys in sy boek: "The Forbidden Zone" (Rutter 1991). Bestaande navorsing toon dat in Amerika ongeveer dertien persent van alle dokters seksuele kontak met hulle pasiënte het (Rutter 1991:41). Hierdie getal is nog hoër onder spirituele leiers, waar sulke optrede allermins verwag word (Rutter 1991:41). Tien persent word egter gebruik by projeksies om moontlike foute uit te sluit.

Corelli ${ }^{4}$ is van mening dat hierdie fenomeen van viktimisering van pasiënte wat in 'n vertrouensrelasie met 'n terapeut staan tien keer meer onder vroulike pasiënte as manlikes voorkom. Hy gaan selfs so ver om te beweer dat die getal onder vroue gereken kan word tot een uit elke vier vroue wat terapie ontvang en dat hierdie vroue geskend kan word vir die res van hulle lewens. Gebroke verhoudings, wantroue in mans, seksuele promiskuïteit, major depressies en ernstige skade aan die selfbeeld is maar van die enkele nagevolge van so 'n daad.

\footnotetext{
${ }^{3}$ Corelli (corelli@leland.stanford.edu).

${ }^{4}$ Corelli (corelli@leland.stanford.edu).
} 
Daar is geen statistiek beskikbaar oor die frekwensie van seksuele verhoudings in hulpverleningsprofessies in Suid-Afrika nie. Indien die Amerikaanse statistiek van tien persent op die situasie in die RSA geprojekteer word op al die dokters, prokureurs, advokate, sielkundiges, pastorale beraders, insluitend alle spirituele leiers van verskillende denominasies in Suid-Afrika, vertoon dit 'n skrikwekkende beeld. In die Amerikaanse staat Kalifornië word hierdie hoë frekwensie in so 'n ernstige lig gesien dat hulle dit as 'n publieke gesondheidsepidemie beskou. ${ }^{5}$

Seksuele flirtasie in die "forbidden zone" kom neer op magsmisbruik of emosionele geweld. Hierdie misbruik van mag deur mans in vertroulike situasies het nie net fisiese gevolge vir die pasiënt nie, maar dit doen afbreuk aan enige vertrouensverhouding waarin die pasiënt in die toekoms mag staan. Dit is dus nie altyd die seksuele daad wat die skade aanrig nie, maar die eksploitering van die vrou se vertroue, tot voordeel van die man.

Maria Lymberis ${ }^{6}$ verwys na hierdie fenomeen as die dokter of sielkundige se selfsugtige belang en eie behoeftes wat gestel word bo die van die pasiënt. Die terapeutiese vertrouensituasie word in so 'n geval juis deur die terapeut misbruik tot bevrediging van eie behoeftes. Rutter (1991:66) toon dat dit daarop neerkom dat die terapeut behandeling vir sy misplaaste behoefte van die pasiënt, wat kom hulp soek het by die terapeut, ontvang.

Blanchard (1991:239) stel dat die vertrouensverhouding in die pastoraat misbruik kan word, omdat die pastorale relasie by uitstek oor besondere eienskappe beskik wat die potensiaal vir misbruik bevorder:

- $\quad$ 'n Oormatige vertroue in die pastor as spirituele leier.

- $\quad$ Die mag en gesag waaroor die pastor op grond van sy rol beskik.

- $\quad$ Intellektuele en akademiese voorsprong wat die pastor gewoonlik bo die pastorant het.

- $\quad$ Die natuurlike behoefte van die pastorant om die pastor tevrede te stel.

- $\quad$ Psigologiese kwesbaarheid van die pastorant in 'n krisissituasie.

- Die pastor se eie kwesbaarheid en tekortkominge.

Die pastorale relasie kan daarom ook getipeer word as 'n "forbidden zone" vir seksuele verhoudings.

\footnotetext{
${ }^{5}$ (http://www.calpsych.com/lymberis/ethical.htm).

${ }^{6}$ Lymberis (http://www.calpsych.com/lymberis/ethical.htm).
} 


\section{Erotiese oordrag en teenoordrag}

\subsection{Definiëring van erotiese oordrag}

Erotiese oordrag is die pasiënt se idealisering van die terapeut tot "ek wens hy was my man fantasie" (Thoburn \& Balswick 1994:292). ${ }^{7}$ Brewster (1996:357) identifiseer ' $n$ paar tipes vroue wat veral vatbaar is vir hierdie oordrag:

- $\quad$ Vroue wat as kinders blootgestel was aan kindermolestering. Hierdie vroue is veral vatbaar vir seks in vertrouensverhoudings, omdat dit reggresseer tot by die verhouding wat sy met haar molesteerder gehad het.

- $\quad$ 'n Ander tipe is die wat haar huweliksmaat wil straf. Party vroue toon hierdie oordrag, omdat sy onseker is oor haarself en haar huweliksverhouding. Deur erotiese oordrag wil sy haar aantreklikheid bevestig.

- Vroue wat huweliksprobleme het, sien in die pastor die ideale man.

- $\quad$ Vroue met "borderline" persoonlikheidsversteuring (Van Biljon 2000).

Geskeide vroue soek na hulp en leiding van enige man wat haar sal help om hierdie trauma te oorkom en ooridealiseer die hulpverlener.

Met hierdie idees in die vrou se onderbewuste begin sy met erotiese oordrag. Sy fantaseer oor die terapeut en stuur eortiese boodskappe na hom hetsy verbaal of nie-verbaal. Hy het vir haar 'n seksuele god geword. Sy sal enige iets doen om nader aan hom te kom of om hom net nie teleur te stel nie. Die vrou dink dat sy haar probleme kan oplos as sy nog nader aan die terapeut kan kom. Daarom wil sy die intimiteit van die verhouding verhoog. Dit beteken nie noodwendig dat sy seksueel met die terapeut wil verkeer nie, alhoewel sy erotiese oordrag openbaar (Rutter 1991:143).

Dit is juis op hierdie stadium wat die terapeut hierdie fenomeen as erotiese oordrag moet herken. Dit is die vrou of pasiënt wat die terapeut ten volle vertrou en die verhouding wil laat groei om sodoende hulp te kry vir haar probleme (Rutter 1991:88). Die verantwoordelikheid lê by die terapeut om hierdie fenomeen te identifiseer en reg te hanteer (Rutter 1991:24). Die terapeut is die een wat nou 'n verantwoordelike besluit moet neem. Gaan hy die vrou help in haar nood of gaan hy die vertrouensituasie uitbuit. Dit is tydens hierdie sensitiewe momente waar die terapeut se korrekte teenoordrag van groot belang is, om te verhoed dat die terapeutiese verhouding nie geskaad word nie.

\footnotetext{
${ }^{7}$ (http://www.keithn.com/frayn/ab-sum.htm).
} 


\subsection{Teenoordrag}

$\mathrm{Knight}^{8}$ beskryf teenoordrag as die terapeut se verstaan van die pasiënt se oordrag en sy reaksie hierop (vgl ook Hopkins 1991:250). ${ }^{9}$ Carson, Butcher en Minneka (1995:634) beskryf teenoordrag as die terapeut se gevoelens wat hy oordra in reaksie op die pasiënt se oordrag. Teenoordrag word nie net beïnvloed deur die pasiënt se oordrag nie, maar die terapeut se agtergrond en eie emosies en behoeftes speel ook 'n primêre rol (Miller \& Jackson 1995:38). Baie terapeute hanteer nie hierdie fenomeen op 'n professionele wyse nie, alhoewel hulle dit as psigologiese fenomeen behoort te identifiseer en hanteer. ${ }^{10}$ Die omvang van die probleem vererger indien die terapeut nie bewus is van oordrag as fenomeen nie. Indien die terapeut nie bekend is met erotiese oordrag as fenomeen nie, sal hy die oordrag verkeerd verstaan en gevoelens soos: die pasiënt is verlief op my; sy wil seksuele omgang met my hê; sy kan my nie weerstaan nie, sal manifesteer. Hierdie gevoelens vorm dan die stimuli vir verkeerde teenoordrag (Rutter 1991:163). Rutter (1991:16) beskou hierdie seksuele reaksie van die terapeut op die pasiënt as die misbruik van gesag en vertroue.

\subsection{Simptome van erotiese oordrag en teenoordrag}

Dit was Kernberg (Meadow 1987:132) wat die eerste keer in 1965 terapeute se aandag op simptome van erotiese oordrag en teenoordrag gevestig het. Hy is van mening dat indien die volgende simptome in die terapeut manifesteer, die gevaarsone reeds betree word:

- $\quad$ withdrawal and lack of empathy

- $\quad$ excesses of self-assuredness based on primitive omnipotence

- abandonment of reality

- $\quad$ submission to the patient

- $\quad$ repetitive excesses of self-doubt

- fear of exposure to one's colleagues

- $\quad$ secrecy about how one works.

(Meadow 1987:140)

Erotiese oordrag kan herken word aan erotiese gedrag van die pasiënt. Voorbeelde hiervan is onder andere: suggestiewe bewegings; lyftaal wat seks

\footnotetext{
${ }^{8}$ Knight (http://microtec.net/drknight/therapysite/special.htm).

${ }^{9} \mathrm{Vgl} \mathrm{ook} \mathrm{http://www.wawhite.org/wawhite/tct.htm}$

${ }^{10}$ (http://www.advocateweb.org/hope/bibliographykc/transference).
} 


\section{Erotiese oordrag en teenoordrag}

veronderstel; 'n oorbeheptheid met seks; onnodige aanraking wat langer duur as normaalweg (Knight: 2000).

Simptome van erotiese teenoordrag kan volgens Rutter (1991:158) na vore kom in gedagtes soos:

- $\quad$ Ek wonder of sy geïnteresseerd is in my.

- $\quad$ Ek wonder of sy daarvan sal hou as ek haar sou aanraak.

- $\quad$ Ek kan nie ophou om oor haar te fantaseer as ek weg is van haar nie.

- Kan ek hiermee wegkom?

Sekere konkrete handelings dui volgens hom ook op erotiese teenoordrag:

- $\quad$ Navrae oor haar sekslewe as dit geen betrekking op die terapie het nie.

- $\quad$ Ek vra haar of sy oor my fantaseer.

- Bewustelike vermindering van die fisiese afstand tussen pastor en pastorant.

- $\quad$ Eksplisiete suggestiewe houding en taalgebruik.

- $\quad$ Rasionalisering van die seksuele daad met die pastorant. Kan iets wat so reg voel so verkeerd wees?

- $\quad$ Die reel van ontmoetings buite spreekure en buite die kantoor.

(Rutter 1991:158-168)

\section{DIE AARD VAN 'N PASTORALE VERHOUDING}

\subsection{Verwagtings van pastor en pastorant}

Pastorale berading kan vergelyk word met 'n terapeutiese verhouding soos in ander hulpverleningsprofessies. Die vereistes wat geld vir 'n gewone terapeutiese verhouding is ook essensiëel vir 'n pastorale relasie. Pastorale berading word dus ook gekonstitueer deur elemente soos: empatie, warmte, kongruensie, gelykheid en vertroue. May (1980:75) beklemtoon dat binne die psigologiese-georiënteerde aspek van die pastoraat dit gaan om selfontdekking, wat plaasvind via empatie en affektiewe inlewing. Pastorale berading kan vanuit verskillende modelle benader word. Ongeag die beradingsmodel wat gekies word, is die basiese vertrouensverhouding tussen pastor en pastorant in enige beradingsmodel van kardinale belang. Louw (1997) se model van "Pastoraat as vertolking en ontmoeting" word as vertrekpunt gekies om die belangrikheid van 'n vertrouensverhouding te illustreer. Hy stel dat die psigologiese beraadmodel gekenmerk word deur elemente soos: "understanding, clarification, acceptance, mutuality, freedom, 
responsibility, inner resources" (Louw 1997:306). Louw (1997:306) poneer dat hierdie elemente daarop dui dat dit in die beraadmodel minder om verbale instruksies gaan en meer om persoonlike behoeftes en gevoelens. Die pastoraat is egter meer as net 'n dialoog tussen twee persone, want in sy wese is pastoraat ' $n$ trialoog. Pastoraat word beskou as ' $n$ vertrouensrelasie tussen pastor en pastorant, maar ook as 'n ontmoeting tussen mens, medemens en God. Louw (1997:58) beskou pastoraat nie net as die lewenshulp of as die uitwerking van gesprekstegnieke en metodes nie. Hy is van mening dat pastoraat geloofshulp as lewenshulp is, omdat die inhoud van die pastoraat die heil in Christus is. Pastoraat is geloofshulp wat die gebroke relasie tussen God, mens en naaste probeer herstel. Louw (1997:61) beskou pastorale handelinge as die representering van God se troos en barmhartigheid. Die basis, vertroue en verwagtings in die pastorale relasie is dus meer gelade as in 'n normale terapeutiese situasie.

Louw (1997:61) maak gebruik van metafore as pastorale style, om sodoende die verwagtings van die pastorale situasie beter te verstaan. Die herdermetafooor waarna Louw (1997:61) verwys, word gebaseer op die sensitiwiteit van die pastor. Die Ou Testamentiese mense het geweet dat hulle veilig en geborge is binne God se herderlike sorg. As verkondiger van die Woord, word die predikant beskou as die man van God wat sal omsien na sy kudde. Die herderlike funksie verteenwoordig dus die pastoraat konkreet as God se sorgsame bystand in nood (Louw 1997:63).

Die diensknegmetafoor daarenteen lê klem op die motief van troos, hulp en bystand Louw 1997:64). In hierdie metafoor bevestig die terapeutiese diens van pastorale bediening as genesing en herstel die heerskappy van die koninkryk van God.

Met die wysheidsmetafoor verwys Louw (1997:66) na Spreuke 9:10, waar wysheid begin met die dien van die Here. Wie die Heilige ken, het werklik insig. Die pastorant kan dus vertrou op die pastor wat God dien en dus oor die wysheid beskik, of veronderstel is om hieroor te beskik.

Teen die agtergrond van die duiding van hierdie metafore is dit verstaanbaar dat die verwagtings wat van die pastor gekoester word byvoorbaat meer gelade is as in die geval van ander hulpverleners. Müller (1996:12) gebruik die narratiewe benadering in die pastoraat en stel dat die pastoraat van jou vra om oor jou grense te beweeg en dit buite jou sekuriteit te waag. Hy konstateer dat die pastor betrokke raak by 'n mede-subjek, die pastor beweeg in die gespreksgenoot se gedagtewêreld. In hierdie relasie vind daar aanpassing plaas wat uitloop op 'n dialoog van gee en neem (Müller 


\section{Erotiese oordrag en teenoordrag}

1997:13). Om 'n gesprek so te betree dat jy jou gedagtewêreld met 'n ander kan deel, veronderstel 'n enorme vertroue, en dit is juis een van die dimensies van pastoraat, 'n vertrouensrelasie. Dit is dus uit die bogenoemde duidelik dat die pastoraat by uitstek ' $n$ vertrouensrelasie is waar jy as pastor by 'n medesubjek betrokke raak om geloofshulp vir hom of haar te bied. Die pastorant vertrou en hoop dat die pastor hom/haar op die regte pad sal lei. Hy/sy gee eintlik sy/haar lewe oor in die hande van die pastor om hom/haar sodoende te begelei tot die regte relasie met God.

Die rol wat aan die pastor toegeken word deur die kerk en die gemeente in 'n pastorale situasie, is die van 'n verantwoordelike persoon wat vertrou kan word en wat as begeleier van die gemeente optree. Daar word van hom verwag om op te tree soos 'n man van God wat sy titel eintlik beaam (herder).

Die vroulike pastorant betree die pastoraat met die volgende vooronderstellings:

- $\quad$ Sy kom soek hulp vir haar probleem en verwag hulp, bystand en ondersteuning.

- $\quad$ Sy verwag dat sy die pastor kan vertrou en dat sy haar mees persoonlike sake met hom kan deel.

- $\quad$ Sy verwag ook dat hy nie misbruik van hierdie vertroue en intieme inligting sal maak nie, omdat sy integriteit as dienaar van God bo verdenking behoort te wees.

Die pastor gaan die pastoraat binne met die volgende moontlike veronderstellings:

- $\quad$ Hierdie pastorant is 'n mens vir wie God liefhet en oor wie God besorg is. Ek moet as pastor hierdie liefde en sorg van God deur my betrokkenheid by die pastorant vergestalt.

- $\quad$ Ek moet hierdie pastorant bystaan, troos, ondersteun, haar probleme probeer oplos en haar tot die beste van my vermoë vanuit die Woord begelei.

Indien die resultate verkry vanuit die navorsing oor oordrag en teenoordrag op die pastoraat van toepassing gemaak word, is dit in die lig van die bogenoemde duidelik dat die pastor en pastorant moontlike slagoffers van hierdie fenomeen kan word. 


\subsection{Manifistering van erotiese oordrag en teenoordrag in ' $n$ pastorale relasie}

Dreyer (1981:51) is van mening dat oordrag in die pastoraat ' $n$ psigologiese feit is. Hy verwys na erotiese oordrag in die pastoraat as positiewe oordrag en beskryf dit as die infantiele verlange na bemoedering, 'n gevoel van afhanklikheid (Dreyer 1981:52). Indien die fenomeen van erotiese oordrag wel in die pastoraat hom voordoen, is dit die pastor se verantwoordelikheid om korrek op te tree. Die pastor is die verantwoordelike persoon in hierdie vertrouensverhouding. Hy is aanspreeklik vir wat in so 'n relasie gebeur. Die formulier vir die bevestiging van Dienaars van die Goddelike Woord verwys na die werk van die predikante ook as opsieners wat toesig moet hou oor die deel van God se huishouding wat aan hulle toevertrou is, sodat alles gepas en ordelik sal geskied (NHK 1983:84). Die pastor is dus die persoon wat in beheer is, hy is die persoon wat die situasie kan ontlont of verkeerde teenoordrag kan openbaar of voorkom.

Maar hoekom reageer vroue juis met positiewe oordrag in 'n pastorale situasie? Thornburn en Balswick (1991:278) wys op die volgende moontlike redes:

- $\quad$ Onkunde ten opsigte van hulle eie erotiese oordrag en teenoordrag van die pastor.

- $\quad$ Die pastor of predikant geniet hoë aansien in die gemeenskap en die vrou kan hierby baat. Wat hulle egter nie insien nie is dat so 'n daad juis skaamte oor haar en die pastor sal bring.

- $\quad$ 'n Verdere rede kan toegeskryf word aan die pastor se ervaring ten opsigte van die hantering van emosionele traumas. Die pastor het skynbaar altyd 'n oplossing of die regte antwoord vir elke probleem.

- Die pastor word ook opgelei om 'n goeie luisteraar te wees as voorwaarde vir effektiewe gespreksvoering. Die vrou daarenteen beskou dit egter anders. Die pastor is altyd bereid om te luister wanneer haar man nie wil nie.

- $\quad$ Die pastor is altyd bereid om te help met probleme selfs al beteken dit 'n bietjie opoffering.

- $\quad$ Die pastor stel altyd belang in haar mening, terwyl haar man haar partykeer afjak.

- Die pastor is oënskynlik die ideale man vir 'n vrou, sy gesinslewe weerspieël dit.

- $\quad$ Die pastor is so saggeaard en gemanierd en hy laat die vrou altyd waardig voel. 


\section{Erotiese oordrag en teenoordrag}

Wat is egter die redes vir die manifistering van verkeerde teenoordrag? Balswick en Thoburn (1991:280) identifiseer die volgende faktore wat tot verkeerde teenoordrag kan meehelp:

- $\quad$ Onkunde ten opsigte van die psigologiese fenomeen erotiese oordrag en teenoordrag.

- $\quad$ Die predikant van 'n gemeente ontvang meer kritiek op sy werk as wat hy komplimente en lof kry. Daarom het die meeste predikante ' $n$ lae selfbeeld en het hy 'n enorme soeke na lof en erkenning. Seks is 'n maklike weg tot hierdie erkenning. Hierdie voortgaan met verkeerdelike teenoordrag is eintlik die gevolg van 'n behoefte aan erkenning.

- $\quad$ Gebroke huwelikverhoudings. Die pastor soek na 'n ander verhouding wat die plek van sy huwelik inneem.

- $\quad$ Nie genoeg ondersteuning van sy vrou ten opsigte van sy werk nie. Dus soek hy iemand anders wat dit wel kan doen.

- $\quad$ Die gevoel ontstaan onder predikante dat hulle altyd raadgee, troos en bystaan en te min van dieselfde behandeling kry. Die misbruik van erotiese oordrag is ' $n$ vinnige kitsresep om sulke behandeling van iemand anders te kry.

- $\quad$ As die predikant se werk hom oorlaai en hy spandeer nie genoeg tyd saam met sy vrou nie, kan erotiese oordrag daarvoor kompenseer.

Laaser (1992:63) beweer dat seksuele verslaafdheid ook onder predikante voorkom. Seksuele verslawing is ' $n$ erkende vorm van verslawing wat soos alkoholisme en ander vorme van verslawing erken en behandel moet word. $\mathrm{Hy}$ is van mening dat hierdie seksueel verslaafde predikante veral vatbaar is vir verkeerde teenoordrag. Nog 'n tipe pastor wat maklik sal oortree in die verbode sone word deur Brewster (1996:354) geïdentifiseer as die Narsistiese persoonlikheidstipe. Hierdie persoonlikheidstipe kom in 'n hoë frekwensie onder predikante voor en hierdie tipe persoon se permanente behoefte na erkenning en aanvaarding is ' $n$ ideale teelaarde vir verkeerde teenoordrag.

\subsection{Konsekwensies van seksuele verhoudings in die "forbidden zone"}

Seksuele verhoudings in die vertrouensituasie van die pastoraat word in so 'n ernstige lig gesien dat dit met bloedskande vergelyk word (Brewster 1996:358). Die metafoor word aan hierdie daad toegeken, omdat die gemeentelid deel is van die familie van die gemeente waar die pastor die rol speel van die ouer. Beide verhoudings naamlik bloedskande en seks in die verbode sone, veronderstel vertroue en afhanklikheid. Die gemeente, soos die familie, weier om die slagoffer te glo. Indien hierdie wanpraktyke wel aan die 
lig kom, word sy beskuldig as die een wat die gemeente en kerk skade aangedoen het. Volgens die gemeente kon hierdie praktyke eerder deur die familie en predikant opgelos word.

Die gevolge wat die misbruik van ' $n$ vertrouensverhouding op die pastor, pastorant en gemeente het, is egter nie soos in die geval van 'n huwelik oorkombaar nie. Die verhouding is vir altyd vernietig sodra dit in die publiek bekend word (Brewster 1996:359). Gewoonlik verlaat 'n groot aantal gemeentelede die gemeente of raak hulle onaktief. Finansiële bydraes in die gemeente neem af en wantroue tussen gemeentelede neem toe. 'n Gevoel van geheimhouding en sinisme kenmerk gemeentebyeenkomste. Die gemeente word mismoedig, want die plek waarnatoe hulle gekom het vir veiligheid en heling het juis die plek geword van uitbuiting.

Die pastor word deur die gemeenskap verwerp en enige vertrouensverhouding wat daar was, is vernietig. Dit is ironies dat die pastor kon dink dat seks die vinnige uitweg kon wees vir erkenning. Nou word dit juis die vernietiging van alle erkenning en aansien en sal die gebeure hom die res van sy lewe teister.

Wat die pastorant betref is sy nog steeds sonder hulp, want geen hulp is aan haar verleen nie, inteendeel sy was die hulpverlener. Sy kan moontlik in depressie verval. Bowendien verwerp almal haar ook as die een wat die predikant verlei het. In uiterste gevalle het dit selfs so 'n groot invloed op die pastorant dat sy moontlik selfs kan twyfel of sy ooit kinders wil hê, omdat sy haarself wantrou (Rutter 1991:103).

Die gevolge kring selfs wyer uit na die volgende predikant in die standplaas. Indien die pastor uit sy amp onthef word en 'n nuwe predikant neem sy plek in, word hy gekonfronteer met probleme soos wantroue en ongelukkigheid oor sy optrede wat eintlik maar 'n rookskerm is vir die vertroue wat gebreek is tydens die vorige predikant se wandade (Brewster 1996:360).

\section{VOORKOMENDE MAATREËLS}

Indien die pastor bewus is van die gevare van erotiese teenoordrag, kan die volgende hanteringsmeganismes help om die verskynsel professioneel te hanteer.

Balswick en Thoburn (1991:278-279) asook Miller en Jackson (1995:34) bespreek 'n paar wenke wat predikante in die praktyk kan toepas om erotiese teenoordrag in die pastoraat te vermy:

- $\quad$ Party vrouens is baie ingestel op fisiese kontak en vat graag aan die pastor. Probeer hierdie gedrag vermy en probeer eerder langs haar staan as reg voor haar. 


\section{Erotiese oordrag en teenoordrag}

- $\quad$ Ken jouself en vermy alle gedrag of situasies wat jy weet vir jou seksueel aanloklik of aantreklik mag lyk.

- $\quad$ Indien jy weet dat 'n vrou aangetrokke tot jou voel, probeer doelbewus minder aandag aan haar gee sonder om haar vertroue in jou te skend.

- In sommige situasies kan 'n predikant selfs sy vrou saamneem as hy weet dat die pastorant baie aantreklik is. Die ouderling of diaken van 'n wyk kan ook saamgenooi word indien die situasie verdag lyk.

- $\quad$ Probeer situasies vermy waar jy besoek aflê by vroue wie se mans by die werk is, of wat uitstedig is.

- $\quad$ Tydens die besondere pastoraat bly jy in jou stoel en sy in hare. Geen uitsondering op die reël.

- $\quad$ Bid vir genade.

- $\quad$ Skep genoeg tyd om saam met jou vrou deur te bring. Baie predikante maak staat op 'n goeie verhouding met hulle vrouens. 'n Gesonde huwelik verminder die kanse dat jy jou sal skuldig maak aan sulke wanpraktyke.

- $\quad$ Bespreek moontlike gevaarsituasies in die pastoraat met 'n medekollega.

- $\quad$ Indien gevaarligte flikker, doen agtergrondnavorsing oor die pastorant by dokters en advokate. Sy het moontlik al dieselfde teenoor hulle opgetree.

- $\quad$ Moet nie met 'n verskuilde agenda na die pastorant gaan nie, stel die afspraak eerder uit of verwys haar na 'n kollega.

- $\quad$ Sien slegs die pastorant in die geskeduleerde tyd.

- $\quad$ Struktueer 'n behoorlike gesprek en hou so na as moontlik hieraan.

\section{HANTERINGSMEGANISMES}

Indien die pastor agterkom dat die pastorant die erotiese oordragfase betree, moet hy dit deur sy optrede duidelik maak dat hy nie 'n behoefte aan 'n seksuele verhouding met haar het nie. Dit is noodsaaklik dat die pastor nie afbreek doen aan die pastorant se vertroue nie, hy kan eerder die fenomeen aan haar verduidelik. Die pastor moet die pastorant daarop wys dat dit iets is wat algemeen voorkom en dat sy nie skaam hoef te wees hieroor nie. Dit is ook nodig om grense neer te lê vir die pastorant en pastor om binne die bakens van 'n gesonde pastorale ontmoeting te beweeg. Indien die erotiese oordrag so sterk is dat die pastor voel dat hy nie meer die grense kan handhaaf nie, moet daar op 'n sensitiewe manier aan die pastorant verduidelik word hoekom sy die pastor nie meer kan spreek nie en waarom hy haar na 'n kollega verwys. 


\section{GEDRAGSKODE VIR DIE PASTOR}

Om die probleem te bekamp, kan die moontlikheid van 'n gedragskode vir predikante oorweeg word.

Fortune (1987:135) poneer dat jy as pastor vertrou word met 'n heilige verantwoordelikheid, om om te sien na God se volk. Brewster (1996:356) stel dat die gemeente die gesag gee aan die predikant, met dien verstande dat dit benut sal word tot die voordeel van die kerk en die gemeentelede. Die pastor is altyd verantwoordelik of aanspreeklik vir die emosionele, spirituele, en fisiese welsyn van persone wat hom nader vir hulp. Fortune (1987:137) is van mening dat die verbreking van so 'n beskermende vertrouensverhouding oneties en ongehoord is. Dit is ondenkbaar dat iemand hierdie vertrouensverhouding, wat geskep is met die oog op hulpverlening aan persone in nood, kan misbruik. Hierdie pastors wat met 'n verskuilde agenda en vir eie belang ' $n$ pastorale situasie betree, moet dadelik gestop word, want dit strek tot nadeel van die pastorant, gemeente en die kerk.

Daar is nie tans 'n gedragskode vir die predikant neergelê nie, maar dit word deur die kerk en gemeenskap geïmpliseer of veronderstel. Indien seks in hulpverlenings-professies, soos die mediese en sielkundige terreine, as oneties en as krimineel strafbaar beskou word, hoeveel te meer moet dit nie van toepassing wees op die pastoraat wat nog 'n groter vertrouensverhouding veronderstel nie. ${ }^{11}$ Die pastor word in 'n gesagsposisie geplaas om te dien en nie om dit te misbruik of te eksploiteer nie. Omdat die pastoraat 'n vertrouensverhouding veronderstel en die pastor beskou word as die persoon met die gesag in die verhouding is dit sy verantwoordelikheid om so op te tree dat die belange van die pastorant altyd eerste gestel word. ${ }^{12}$

Gedragskodes in ander hulpverleningsprofessies stel dit duidelik dat sulke wanpraktyke nie geduld sal word nie. Die Amerikaanse Psigologiese Assosiasie se etiese prinsipes vir sielkundiges 1989 stel die saak so: ${ }^{13}$

Principle 6a: Sexual intimacies with clients are unethical.

Principle 6d: Psychologists do not exploit their professional relationships with clients, supervisees, students, employees, or research participants, sexually or otherwise.

Psychologists do not condone or engage in sexual harassment.

\footnotetext{
${ }^{11}$ (http://www.wwlia.org/us-prosx.htm).

${ }^{12}$ (http://www.wwlia.org/us-prosx.htm).

${ }^{13}$ (http://www.calpsych.com/lymberis/ethical.htm).
} 


\section{Erotiese oordrag en teenoordrag}

Die Kode vir Professionele etiek van die Amerikaanse Assosiasie vir Huweliks- en Gesisnsterapie (1988) stel dat: ${ }^{14}$

Section 1.2: Marriage and family therapists are cognizant of their potentially influential position with respect to clients, and they avoid exploiting the trust and dependency of such persons. Marriage and family therapists therefore make every effort to avoid dual relationships with clients that could impair their professional judgement or increase the risk of exploitation. Examples of such dual relationships include, but are not limited to business or close personal relationships with clients.

Sexual intimacy with clients is prohibited. Sexual intimacy with former clients for two years following the termination of therapy is prohibited.

'n Moontlike gedragskode vir predikante kan dalk die volgende aspekte beklemtoon:

- Die behoeftes en belange van die pastorant is belangriker as die van die pastor.

- $\quad$ Die pastoraat is gebaseer op 'n vertrouensverhouding. Die pastor moet seksuele verhoudings met 'n pastorant ten alle tye vermy.

- $\quad$ Die vooronderstellings waarop die pastoraat gebou is, naamlik: eerlikheid, vertroue en getrouheid word alleen gebruik tot voordeel van die pastorant.

- $\quad$ Dit is die pastor se verantwoordelikheid om die grense van erotiese teenoordrag te eerbiedig.

- Die fenomeen erotiese oordrag moet, indien manifestering plaasvind, geïdentifiseer en korrek benader word.

- $\quad$ Die pastor is ten alle tye verantwoordelik en aanspreeklik vir wat in die pastorale relasie plaasvind.

- $\quad$ Indien enige kollega of gemeentelid weet van 'n pastor wat die vertrouensverhouding van die pastoraat misbruik, is dit sy of haar plig om dit te rapporteer.

- $\quad$ Misbruik van die pastorale relasie sal tot noodwendige verlies van ampsvoorregte lei.

"Let us remember: What hurts the victim the most is not the cruelty of the opressor, but the silence of the bystander." Ellie Wiesel (Rutter 1991:1)

$\overline{{ }^{14} \text { (http://www.calpsych.com/lymberis/ethical.htm) }}$ 


\section{KONKLUSIES}

Met hierdie studie is gepoog om die psigologiese fenomeen "erotiese oordrag" en "teenoordrag" as verskynsel in die pastoraat te beskryf, sodat predikante bewus gemaak kan word daarvan en sodat hulle dit makliker kan herken en voorkom in die pastoraat. Deur predikante meer bewus te maak van die voorkoms van hierdie fenomeen, ook in die pastoraat, sal hierdie wanpraktyke in die pastoraat hopelik afneem.

Hierdie fenomeen wat soveel skade kan veroorsaak aan 'n vertrouensverhouding moet betyds herken word. Om hierdie fenomeen betyds te herken moet predikante eers bewus gemaak word van die verskynsel in 'n pastorale relasie, asook die hoë frekwensie daarvan. Tog is daar geen artikels oor die saak gepubliseer in die Kerk se tydskrifte en koerante nie. In die opleiding word daar net kortliks na hierdie psigologiese fenomeen verwys.

Predikante en teologiese studente moet deur artikels, kursusse en in die teologiese opleiding deeglik bewus gemaak word van erotiese oordrag en teenoordrag, asook die aanleidende faktore, hanteringsmeganismes en voorsorgmaatreëls. Dit kan die frekwensie van sulke wanpraktyke moontlik laat afneem. Sulke wanpraktyke in die bediening moet in 'n ernstige lig gesien word en moontlike optredes moet ooreenkom met die erge graad van eksploitering van die vertrouensituasie. Hierdie fenomeen moet ook bekend gemaak word aan gemeentelede wat die pastoraat betree. Deur dit te doen maak dit die pastorant bewus van hierdie faset van ' $n$ vertrouensverhouding, sodat sy haar intimiteitsgevoelens sal sien as vertroue en haar soeke na hulp en nie die behoefte na seks nie. Predikante, asook gemeentelede, moet bewus gemaak word van die grense van die vertrouensverhouding in die pastoraat, sodat die pastoraat tot sy reg kan kom as 'n vertrouensituasie tussen pastor, pastorant en God.

Daar moet in die kerk besin word oor die bruikbaarheid van die insluiting van 'n moontlike gedragskode in die kerkorde wat elke proponent en predikant moet onderteken, om sodoende die regte beroepsetiek te bevorder. Hulpmiddels vir die daarstelling van 'n gedragskode kan geskrifte insluit soos die eed vir medici, asook die etiese kode vir sielkundiges en beraders.

\section{Literatuurverwysings}

Balswick, J O \& Thoburn, J 1991. How ministers deal with sexual temptation. Pastoral Psychology 39, 277-286.

Balswick, J O \& Thoburn, J 1994. An evaluation of infedelity among male protestant clergy. Pastoral Psychology 42, 285-294.

Balswick, J O \& Thoburn, J 1995. A prevention approach to infedelity among male protestant clergy. Pastoral Psychology 42, 45-51. 


\section{Erotiese oordrag en teenoordrag}

Blanchard, G T 1991. Sexually abusive clergymen: A conceptual framework for intervention and recovery. Pastoral Psychology 39, 237-245.

Brewster, A B 1996. Clergy sexual misconduct: The affair everyone remembers. Pastoral Psychology 44, 353-361.

Carson, C R, Butcher, N J \& Mineka, S 1995. Abnormal psychology in modern life. Minnesota, MN: Harper Collins College.

Corelli, R 2000. corelli@leland.stanford.edu.

Dreyer, T F J 1981. Poimeniek: 'n Pastorale oriëntasie. Pretoria: Kital.

Fortune, M M 1989. Is nothing sacred: When sex invades the pastoral relationship. San Francisco, CA: Harper \& Row.

Freud, S [1927] 1961. Postscript to the question of lay analysis, in Strachey, J (ed), The Standard Edition of the Complete Psychological Works of Sigmund Freud, 194-275. Standard Edition. London: Hogarth Press

Hopkins, N M 1991. Congregational intervention: When the pastor has committed sexual misconduct. Pastoral Psychology 39, 247-255.

http://www.advocateweb.org/hope/bibliographykc/transference.as

http://www.keithn.com/frayn/ab-sum.htm.

http://www.wawhite.org/wawhite/tct.htm.

http://www.wwlia.org/us-prosx.htm.

Knight, B 2000. Psychotherapy: Special kind of love. http://microtec.net/drknight/therapysite/special.htm

Laaser, M R 1992. The secret sin: Healing the wounds of sexual addictions. Michigan, Ml:Zondervan.

Loewald, H W 1998. Transference-Countertransference. Journal of the American Pschyoanalytic Association 34, 275-287.

Lymberis, M T 2000. Ethical and legal issues in group psychotherapy. http://www.calpsych.com/lymberis/ethical.htm

Mansfield, $\vee$ 1996. On the physics and psychology of the transference as an interactive field. Presented for publication in Journal of Analitical Psychology.

May, R 1980. The art of counseling. Nashville, TN: Abingdon.

Meadow, P W 1987. The myth of the impersonal analyst. Modern Psychoanalysis 12(2), 131-150.

Miller, W R \& Jackson, K A 1995. Practical psychology for pastors. New Jersey, NJ: Prentice-Hall.

Natterson, J 1991. Beyond countertransference: The therapist's subjectivity in the therapeutic process. London: Aronson.

Nederduitsch Hervormde Kerk van Afrika. Almanak 2000. Jaargang 94. Pretoria: Sentik.

Nederduitsch Hervormde Kerk van Afrika. Notules van die Algemene Kommissievergaderings 1990-2000. Argief van die Nederduitsch Hervormde Kerk, Pretoria.

Nederduitsch Hervormde Kerk van Afrika. Diensboek, 1983. Pretoria: Kital.

Rutter, P 1991. Sex in the forbidden zone. New York, NY: Fawcett Crest.

Schaeffer, J A 1998. Transference and countertransference interpretations: Harmful or helpful in short-term dynamic therapy? American Journal of Psychotherapy 52, 1-17.

Seaman, A R 1999. Swagga : The unauthorized biography of an American evangelist. New York, NY: Continuum. 
Sutherland, P K 1997. Sexual abuse by therapists, physicians, attorneys, and other professionals. http://www.wwlia.org/us-prosx.htm.

Van Biljon, J A 2000. Ongepubliseerde klasaantekeninge, Praktiese Teologie 600, Fakulteit Teologie, Universiteit van Pretoria.

Welles, J K \& Wrye, H K 1997. The narration of desire: Erotic transference and countertransference. JAPA 45, 1. 